\title{
COMPARISON OF THE MONITORED AND MODELED SOIL WATER STORAGE OF THE UPPER SOIL LAYER: THE INFLUENCE OF SOIL PROPERTIES AND GROUNDWATER TABLE LEVEL
}

\author{
JÚLIUS ŠÚTOR, VLASTA ŠTEKAUEROVÁ, VILIAM NAGY \\ Institute of Hydrology, Slovak Academy of Sciences, Račianska 75, 83102 Bratislava, Slovakia; Mailto: stekauerova@uh.savba.sk
}

In the study of Tomlain (1997) a soil water balance model was applied to evaluate the climate change impacts on the soil water storage in the Hurbanovo locality (Southwestern Slovakia), using the climate change scenarios of Slovakia for the years 2010, 2030, and 2075 by the global circulation models CCCM, GISS and GFD3. These calculations did not take into consideration neither the various soil properties, nor the groundwater table influence on soil water content. In this study, their calculated data were compared with those monitored at the same sites. There were found significant differences between resulting soil water storage of the upper $100 \mathrm{~cm}$ soil layer, most probably due to cappilary rise from groundwater at sites 2 and 3. It was shown, that the soil properties and groundwater table depth are importat features strongly influencing soil water content of the upper soil layer; thus the application of the soil water balance equation (Eq. (1)), neglecting the above mentioned factors, could lead to the results far from reality.

KEY WORDS: Soil, Water Storage, Groundwater Table, Water Content, Monitoring, Climate Change.

Július Šútor, Vlasta Štekauerová, Viliam Nagy: POROVNANIE MONITOROVANÝCH A MODELOVANÝCH ZÁSOB VODY V POVRCHOVEJ VRSTVE PÔDY: VPLYV PÔDNYCH VLASTNOSTÍ A HLADINY PODZEMNEJ VODY. J. Hydrol. Hydromech., 58, 2010, 4; 6 lit., 2 obr.

V práci Tomlaina (1997) bol aplikovaný bilančný model vodného režimu pôd na ohodnotenie dopadu klimatickej zmeny na vodné zásoby pôdy v lokalite Hurbanovo (juhozápadné Slovensko), použijúc scenáre klimatickej zmeny pre Slovensko pre roky 2010, 2030 a 2075, založené na globálnych cirkulačných modeloch CCCM, GISS a GFD3. V týchto výpočtoch nebol braný do úvahy vplyv vlastností pôdy a hladiny podzemnej vody na vlhkost' pôdy. V práci boli porovnané vypočítané hodnoty zásob vody s monitorovanými v tej istej lokalite. Bol nájdený význačný rozdiel medzi zásobami vody v 100-cm hornej vrstve pôdy najpravdepodobnejšie spôsobený kapilárnym prítokom od hladiny podzemnej vody v monitorovacích miestach 2 a 3. Bolo ukázané, že pôdne vlastnosti a híbka hladiny podzemnej vody sú dôležitými faktormi, ktoré silno ovplyvňujú vlhkost' hornej vrstvy pôdy; z toho vyplýva, že aplikácia bilančnej rovnice (rov. (1)), ktorá zanedbáva vyššie uvedené faktory, nedáva reálne výsledky.

KLÚČOVÉ SLOVÁ: pôda, zásoba vody, hladina podzemnej vody, vlhkost' pôdy, monitoring, klimatická zmena.

\section{Introduction}

Climate change scenarios predict an air temperature increase and atmospheric precipitation change in the future. Water from precipitation penetrates through the vegetation cover and the soil surface into the soil zone. Here it is accumulated, stored and redistributed into the lower soil layers, and eventually recharges groundwater, or is supplied from groundwater by capillary rise. Part of this water can contribute to the subsurface runoff. It is therefore likely, that climate change will influence both, the soil water storage and the soil water regime.

The basic method of the soil water content data assessment is the systematic measuring (monitoring) of the defined soil layer thickness water content. However, up to the present no systematic soil water content (soil water storage) monitoring systems exist over the territory of Slovakia. Such monitoring systems did not exist in the past either. Therefore, there was no monitored soil water con- 
tent data available that could be used to predict future soil the water storage changes, by extrapolation of soil water content time series. However, soil water content can be calculated by the application of simulation models or by application of the water balance equation of particular soil layer. This makes possible to quantify the climate change impacts on the soil water storage using the above mentioned climate change scenarios of the mean monthly air temperature and precipitation changes. For the territory of Slovakia climate change scenarios were prepared for the time horizons of 2010, 2030, and 2075 (Lapin et al., 1995), using the global circulation models CCCM, GISS, and GFD3. For the adaptation of these scenarios to the site conditions, time series of the observed meteorological elements from a reference period between 1951 and 1980 have been used.

Soil water content of the particular soil layer during the vegetation period, is determined by the family of meteorological, soil, groundwater and canopy data. Using the simple soil water balance model, monthly totals of precipitation, calculated evapotranspiration and subsurface outflow can be used to calculate soil water storage for particular soil layer (Tomlain, 1994, 1997):

$P=E+O+\left(W_{2}-W_{1}\right)$,

where $P$ is the precipitation [mm], $E$ - the actual evapotranspiration $[\mathrm{mm}], O-$ the unsaturated soil zone outflow [mm], $W_{1}$ and $W_{2}$ - the unsaturated soil layer water storages at beginning and at the end of the balanced period. $\left(W_{2}-W_{1}\right)$ is expressing the water storage change in the specified unsaturated soil zone [mm].

Eq. (1) is applicable only for conditions when the groundwater table has no influence on the soil water regime of the selected unsaturated soil zone. This occurs when the groundwater table is very deep or fluctuates in the gravel subsoil.

Tomlain (1997) discussed the possible climate change impacts on the soil water storage at the Hurbanovo locality ( $\left.\alpha=47^{0} 52^{\prime}, \lambda=18^{0} 12^{\prime}\right)$ for the years 2010,2030 and 2075 . He used climate scenarios and a calculation model developed by Hrvol' and Tomlain (1992). The model input parameters are: mean monthly data on the air temperature, cloudiness, water vapour pressure, number of days with snowcover and on precipitation. Monthly water storage values were calculated for the upper 100 $\mathrm{cm}$ soil layer. For these calculations, neither the soil type, nor the groundwater table level were taken into account. In the above mentioned study (Hrvol' and Tomlain, 2007), there were presented calculated monthly average soil water storages for Hurbanovo site, but retrospectively for the period from 1951 to 2005. The Hurbanovo climatological station data were used in his this study. However, similarly to the previous studies, no attention has been paid to the impacts of the soil properties and of the groundwater table level on soil water storage. Due to the lack of soil water content data in this region, it was not possible to verify the applied methodologies. Since the year 2008, a soil water content monitoring system has been established in three sites of the Hurbanovo region. The sites differ in the soil properties and in the groundwater table depth. These sites are under particular attention of climatologists, because of the longest observation period of the meteorological elements in Central Europe at the Hurbanovo meteorological station.

The aim of this study is to compare monitored soil water storage in the upper $100 \mathrm{~cm}$ soil layer, with those modeled by Hrvol' and Tomlain (2007), and thus to verify the possibilty to apply simple soil water balance equation to assess the influence of climate changes on soil water storage at three different sites near Hurbanovo, for the season 2010.

\section{Soils and sites}

The method, used in this study for assessing the water storage in the unsaturated soil zone is based on direct soil water content measurements. Hurbanovo area was choosen because of its climatological station one of the oldest in Central Europe with continuous observations of the meteorological elements. On the Great Danube Lowland (where Hurbanovo is located), seven soil types can be found, as classified by their particle size composition. Sandy-loamy and loamy soils cover $66 \%$ while sandy clays cover $23 \%$ of the area. The rest $11 \%$ are sandy soils, loamy sands, clayey loams and clays. The physical, hydrophysical, physicochemical and biological properties of these soils can be evaulated using information on soil texture. Soil water content monitoring has been organized on three sites around the Hurbanovo municipality in a monthly frequency. Measurements were performed by the gravimetric method using samples, taken from the surface up to $130 \mathrm{~cm}$ depth in $10 \mathrm{~cm}$ resolution.

Three soil water content monitoring sites were selected:

Site $1,\left(\alpha=47^{\circ} 53^{\prime} 39.7^{\prime \prime}, \lambda=18^{\circ} 12^{\prime} 08^{\prime \prime}\right)$ : loamy-sand (I. category fraction content according 
to Kopecky classification is in the interval 10 to $20 \%$ ).

Site $2,\left(\alpha=47^{\circ} 52^{\prime} 40.2^{\prime \prime}, \lambda=18^{\circ} 10^{\prime} 58.6^{\prime \prime}\right)$ : loam - L (I. category fraction content according to Kopecky classification is in the interval 30 to $45 \%$ ).

Site 3, $\left(\alpha=47^{\circ} 49^{\prime} 40.1^{\prime \prime}, \lambda=18^{\circ} 10^{\prime} 26.5^{\prime \prime}\right)$ : sandy-loam - SL (I. category fraction content according to Kopecky classification is in the interval 20 to $30 \%$ ).

None of the last two sites (site 2 and 3 ) has a gravel subsoil, delineating the groundwater table from the upper soil layers and thus eventually blocking the capillary rise to the soil layer.

Groundwater table around Hurbanovo area is under a strong influence of the water level changes in the nearby Danube and Váh rivers. Groundwater table depth at the site 1 , is fluctuating within depths of 6-7 $\mathrm{m}$ below soil surface, at site 2 groundwater table depth is oscillating around $4 \mathrm{~m}$ and at site 3 in the depth interval 2.5-3 meters below the soil surface in average. The monitoring sites 2 and 3 were selected, taking into consideration the groundwater tables depths and their possible influence on the soil water content in the upper, one meter soil layer.

Differentiation of groundwater table in combination with the various soil types presents a possibility to evalute the unsaturated soil zone water storage dynamics and its possible interaction with the groundwater table below.

\section{Results and discussion}

In the vegetation period of 2008, 2009 and partially 2010 the soil water content dynamic was measured at the three sites nearby Hurbanovo using the gravimetric method. From the measured soil water content data, the soil water storage $W_{p}$ was calculated for the soil upper, $100 \mathrm{~cm}$ soil layer.

These monitored $W_{p}$ values for the sites near Hurbanovo were compared with those predicted by Tomlain (1997) using the CCCM, GISS and GFD3 scenarios for the Hurbanovo area, both for the season 2010. Results are presented in Fig. 1.

Mean water storage values of the upper $100 \mathrm{~cm}$ soil layer for March, April, and May are shown in Fig. 2, from the study by Hrvol' and Tomlain (2007) presenting the long-term (1951 to 2005) soil water content trends for Hurbanovo, together with the monitored $W_{p}$ for the summer season from 2008 to 2010 in the same soil layer at the three above mentioned sites.

From the results presented (Figs. 1,2) it can be seen significant - even more than $200 \%$ - differences between measured and simulated soil water storages. Especially during autumn months, the differences between measured and calculated soil water storages are about $150 \mathrm{~mm}$ of water layer in the upper 1 meter soil layer.

Comparing the upper $100 \mathrm{~cm}$ soil layer water storage monitoring results on the three sites nearby a Hurbanovo for years 2008, 2009 and 2010 it can be shown, that in the upper, $100 \mathrm{~cm}$ soil layer the water storage depends on the soil properties and on the the groundwater table level too. The results indicated, that the soil water regime at sites 2 and 3 was strongly influenced by the groundwater table level below the soil surface, due to the continuous capillary rise, thus increasing the soil water content and soil water storage in the soil profile as well. In such a case, when groundwater is interacting with the upper soil layer, simple water balance model expressed by the Eq. (1) cannot be applied.

The monitored and modelled soil water storage values of the upper $100 \mathrm{~cm}$ soil layer were close at site 1 only. The groundwater table depth below soil surface at that site was always at the minimum depth $6 \mathrm{~m}$, therefore the soil water content at the upper 1 meter soil layer at this site is not influenced by the groundwater fluctuations, the Eq. (1), which was the base for the model approach of Hrvol' and Tomlain (1992), can be applied.

Evaluation of the mean water storage values calculated by the modell for the months of March, April, and May of the 1951-2005 period (Fig. 2) indicates, that this case is similar to that of the predicted results for the 2010 season. An agreement between the monitored and modelled soil water storage values could be found at site 1 only. At the other sites, the modelled and monitored data differs significantly.

Continuation of monitoring in the future is of a great importance. It is the source of basic data needed to validate the predictive methods. The monitoring results will extend our knowledge about the climate change impacts on the unsaturated soil zone water storage changes. It will also give an opportunity to investigate the possible model applications for predicting the climate change effects on soil water regime. There is possible to use modern electromagnetic methods, giving reliable results and allowing continuous record of soil water content (Loiskandl et al., 2010). 


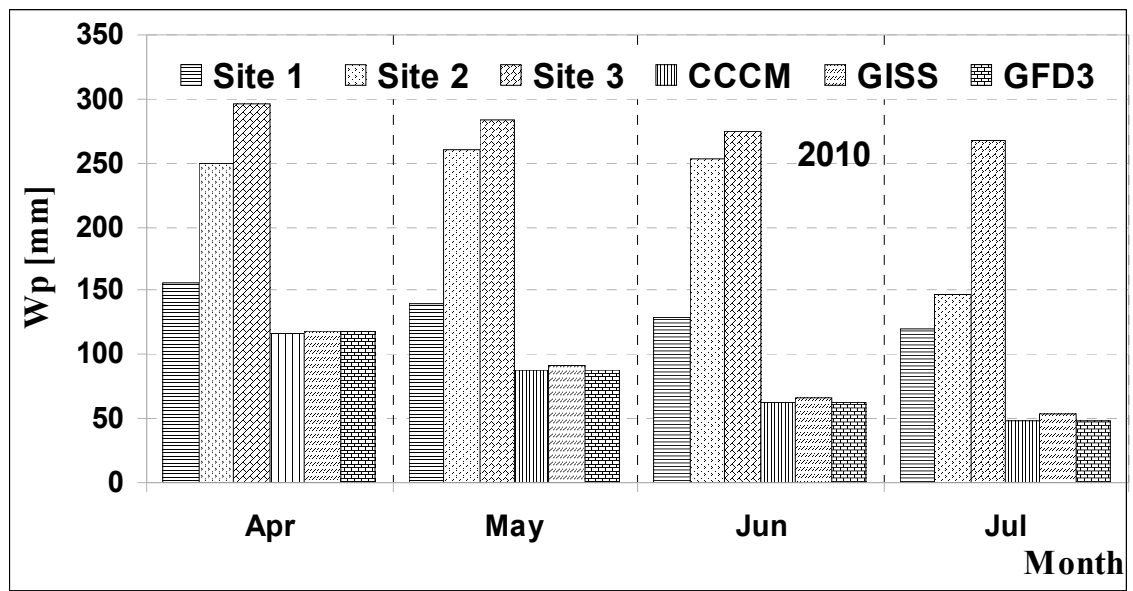

Fig.1. Comparison of the monitored soil water storages $W_{p}$ of the upper 100-cm soil layer and season 2010 (site 1, 2 and 3 ) with those calculated for 2010 season by Tomlain (1997), using the CCCM, GISS and GFD3 scenarios in the locality Hurbanovo.

Obr. 1. Porovnanie monitorovaných zásob vody $W_{p}$ v hornej $100-\mathrm{cm}$ vrstve pôdy v roku 2010 (monitorovacie miesta 1,2 a 3) s vypočítanými podla Tomlaina (1997) pre rok 2010 použijúc scenáre CCCM, GISS a GFD3 v lokalite Hurbanovo.

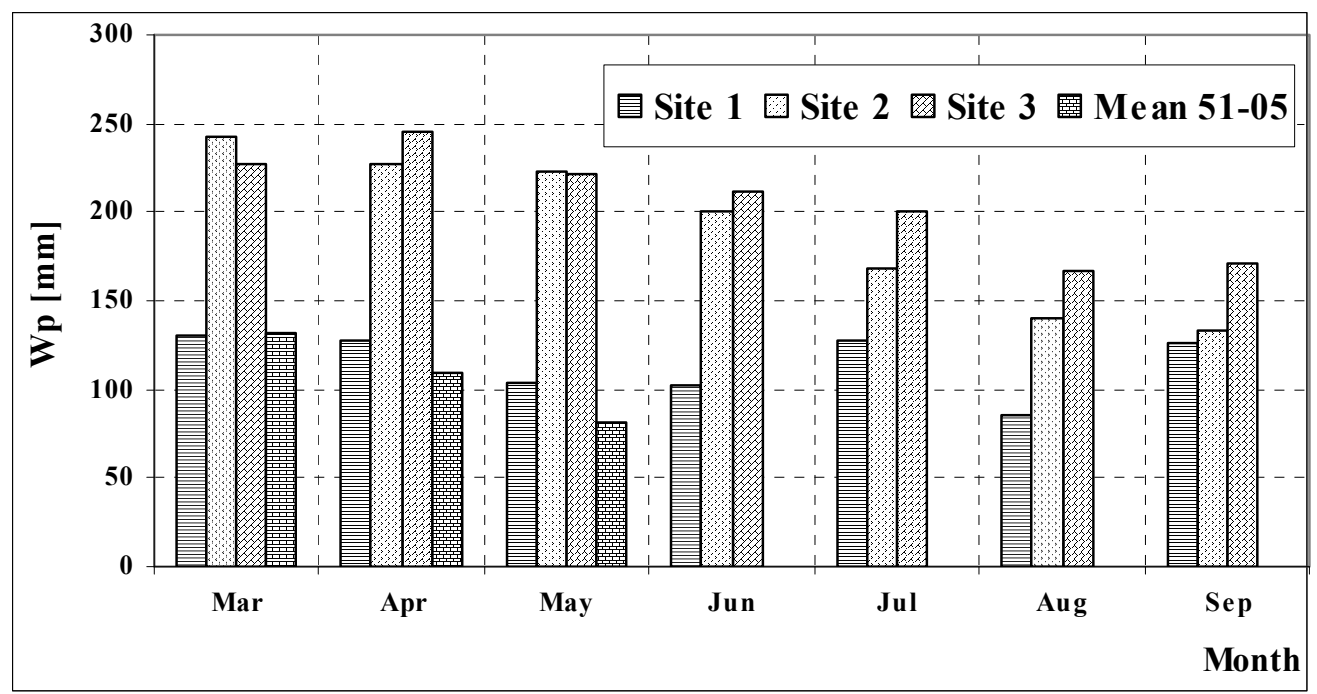

Fig. 2. Monitored mean monthly soil water storage $W_{p}$, in the upper100-cm soil layer, in months March to September 2008 , 2009 and in months March to July 2010 on the monitored sites 1, 2, and 3 and modelled mean water storage in the upper100 cm soil layer in months March, April, and May of the period 1951 to 2005 period (Hrvol', Tomlain, 2007) in the locality Hurbanovo.

Obr. 2. Monitorované priemerné mesačné zásoby vody $W_{p} \mathrm{v}$ hornej $100-\mathrm{cm}$ vrstve pôdy $\mathrm{v}$ mesiacoch marec až september 2008 , 2009 a v mesiacoch marec až júl 2010 na monitorovaných miestach 1, 2 a 3 a modelované priemerné mesačné zásoby vody v hornej 100-cm vrstve pôdy v mesiacoch marec, apríl a máj počas rokov 1951 až 2005 (Hrvol', Tomlain, 2007) v lokalite Hurbanovo.

\section{Conclusion}

In this study, the evaluation of the soil water storage in the upper 100-cm soil layer is based on soil water content measurement since 2008. Soil water content monitoring is being carried out at the three sites of the Hurbanovo area. These three sites differ in soil properties and groundwater table level depths with different impact on the upper soil layer water content. Fair agreement between the monitored and modelled water storage - by the soil water balance equation - in the upper one meter soil layer was found only at site 1, where the groundwater has no influence on soil water regime and Eq. (1) can be applied. It can be concluded, that the model offered by Hrvol' and Tomlain (1992) to forecast changes in the soil water storage cannot be used for sites 2 and 3, where the groundwater inter- 
acts with the upper soil layer. This model neither reflects the groundwater table, nor the soil characteristics influence on soil water content and results are unrealistic.

For predicting the climate change impacts on the soil water regime it is especially important to take into consideration the main influencing factors fo this regime. Otherwise, misleading results can be obtained.

Acknowledgements. This work was partially supported by the projects: VEGA 2/0120/08, VEGA 1/0319/09, APVV-0271-07, and APVT 51 019804.

\section{REFERENCES}

HRVOL J., TOMLAIN J., 1992: Model computation of active surface temperature on the territory of Slovakia. Acta Meteorologica Universitatis Comenianae, Vol. XXI, Bratislava, 33-45.

HRVOL' J., TOMLAIN J., 2007: Long-term changes of the soil moisture in spring at Hurbanovo for the period 1951-2005. (In Slovak.) (Dlhodobé zmeny vlhkosti pôdy na jar v Hurbanove za obdobie 1951 až 2005. In: XV. posterový deň s medzinárodnou účast'ou „Transport vody, chemikálii a energie v systéme pôda-rastlina-atmosféra", Bratislava, 15. nov. 2007.) In: XV. International Poster Day "Transport of Water, Chemicals and Energy in the System Soil-Crop Canopy-Atmosphere“, Bratislava, Nov. 15, 2007, 189-197.

LAPIN M., NIEPLOVÁ E., FAŠKO P., 1995: Climate Scenarios for Air Temperature and Precipitation Change in Slovakia. (In Slovak.) (Regionálne scenáre zmien teploty, vzduchu a zrážok na Slovensku. In: Národný klimatický program SR, II.) In: National Climate Programme of the Slovak Republic, II, Vol. 3, Bratislava, 19-57.

LOISKANDL W., BUCHAN G.D., SOKOL W., NOVAK V., HIMMELBAUER M., 2010: Calibrating electromagnetic short soil water sensors. In: J. Hydrol. Hydromech., 58, 2, $114-125$.

TOMLAIN J., 1994: Consequences of Basic Climatic Characteristics Changes on Changes of Soil Moisture in Chosen Sites of Slovakia. (In Slovak.) (Dôsledky zmien základných klimatických charakteristík na zmeny obsahu vody v pôde na vybraných lokalitách Slovenska.) Acta Meteorologica Universitatis Comenianae, Vol. XXIII, Bratislava.

TOMLAIN J., 1997: Model computation of the Climate Change Impacts upon Soil Moisture on the Territoty of Slovakia. (In Slovak.) (Modelový výpočet dôsledkov očakávanej zmeny klímy na obsah vody v pôde na Slovensku.) In: Národný klimatický program SR, IV - Príspevok ku scenárom klimatickej zmeny na Slovensku.) In: National Climate Programme of the Slovak Republic, IV - Contribution to the Climate Change Scenarios for Slovakia. Vol. 7, Bratislava, 68-83.

Received August 4, 2009

Accepted October 26, 2010

\section{POROVNANIE MONITOROVANÝCH \\ A MODELOVANÝCH ZÁSOB VODY V POVRCHOVEJ VRSTVE PÔDY: VPLYV PÔDNYCH VLASTNOSTÍ A HLADINY PODZEMNEJ VODY}

\section{Július Šútor, Vlasta Štekauerová, Viliam Nagy}

V tejto práci je ohodnotenie zásob vody v $100 \mathrm{~cm}$ hornej vrstve pôdy založené na meraní vlhkosti pôdy od roku 2008. Vlhkost' pôdy bola sledovaná v troch monitorovacích miestach v oblasti Hurbanova. Tieto tri monitorovacie miesta majú odlišné pôdne vlastnosti a rôzny dopad hladiny podzemnej vody na vlhkost' hornej vrstvy pôdy. Dobrá zhoda medzi monitorovanými a modelovanými zásobami vody - použitím bilančnej rovnice $-\mathrm{v}$ hornej $100 \mathrm{~cm}$ vrstve pôdy bola len $\mathrm{v}$ monitorovacom mieste 1 , kde podzemná voda neovplyvňovala vodný režim pôd a rov. (1) mohla byt' použitá. $Z$ toho vyplýva, že model Hrvol'a a Tomlaina (1992) na prognózovanie zmien v zásobách pôdnej vody nemôže byt' použitý pre monitorovacie miesta 2 a 3, kde hladina podzemnej vody interaguje s hornou vrstvou pôdy. Model neuvažuje vplyv hladiny podzemnej vody ani vplyv charakteristík pôdy na vlhkost' pôdy a $\mathrm{v}$ tomto prípade nedáva reálne výsledky. 